6. Sundari, $\mathrm{H}$. The features of mediation in EFL classroom interaction: Teacher perspectives. Indonesian EFL Journal, 2020. 6(1), P. 35-44. DOI: 10.25134/ieflj.v6i1.2636.

7. Волік В.В. Медіація та іiі місце у процесі навчання іноземної мови. Журнал науковий огляд. № 8(61), 2019. С. 91-104.

8. Єрастова-Михалусь І., Ципіна Д. Формування медіативної компетентності у процесі вивчення професійно-орієнтованої іноземної мови. Актуальні питання гуманітарних наук, 2020. Вип. 27, том 2, C. 206-210.

9. Мольдерф О. Медіація і професійна перекладацька діяльність в контексті оновлення загальноєвропейських рекомендацій з мовної освіти. Іноземна філологія, 2018. № 131. С. 71-80.

10. Ципіна Д. С. Дидактичні засоби формування медіативної компетентності на занятті з іноземної мови. Вісник Запорізького національного університету. Педагогічні науки, 2020. № 1 (34). C. 366-372.

DOI https://doi.org/10.30525/978-9934-26-180-0-51

\title{
THE PECULIARITIES OF TEACHING ENGLISH TO STUDENTS WITH DYSLEXIA
}

\author{
Zaika A. Yu. \\ Senior lecturer at the English Language Department \\ National University of Kyiv-Mohyla Academy \\ Kyiv, Ukraine
}

Learning foreign languages is an integral and obligatory part of the educational system of Ukraine. It is known that one of the most important types of communicative activity of students of higher educational institutions is reading, which is aimed at extracting information from a written fixed text. Reading provides students with a opportunities to develop their skills, including learning English. To learn to read correctly, it is necessary to understand what is being read correctly, to see what is written correctly and to correlate it correctly with what is pronounced. Disorder of the reading process, which makes it difficult to master this skill and leads to many mistakes during reading (omission of letters, syllables, their replacement and rearrangement, omission 
of prepositions, conjunctions, replacement of words with one another, omission of lines, etc.) is called dyslexia [2, p.178].

The problem of impaired reading and writing remains one of the most urgent. Modern scientific ideas about the symptoms, mechanisms and classification of dyslexia and dysgraphia, about the methods of their detection, correction and prevention were developed in stages and are presented in the works of A. Luria, S. Mnukhin, R. Tkachev, A. Kornev, R. Levina, I. Sadovnikova, M. Khvatseva and etc.

Although there are many scientific papers on dyslexia, the problem of teaching English to students with reading and writing disabilities is not well understood. Considering the high prevalence of students with a specific reading disorder and its impact on academic performance in general, the need for a comprehensive psychological and pedagogical approach to overcoming it is obvious.

It is important to note that when learning English, dyslexic students have low self-esteem and low learning motivation. Therefore, an individual approach to such students must include a conversation with an analysis of the difficulties that students experience when completing assignments / reading texts and fixing success in overcoming them [1, p. 203].

How can a teacher help a dyslexic student learn a foreign language? First, the instructor must make sure that the instructions / assignments are clear and appropriate, meet the specific needs of the students, and that the students understand what is expected of them. Second, allow sufficient time for students to read and analyze the question or assignment before answering. Thirdly, for a better understanding of the material, you can use mind maps, pictures, colored pens and crayons and other visualized materials [3, p. 112].

Now we would like to indicate the features of teaching various language skills to students with dyslexia, checking listening, reading, writing and grammar.

Before proceeding directly to the listening assignment, it is worthwhile to study certain words in advance - pre-listening vocabulary. It is also necessary to minimize the number of words with similar sounding in the text, for example, night and knight, no and know, etc. Difficulties can arise with assignments in which you need to listen and read at the same time. Therefore, the best solution would be to use pictures, one of which is the answer to the question. Then the student will need to choose an answer just by looking at the pictures.

The best exercises to practice reading are exercises where the student listen to and reads the text at the same time. It helps develop technical reading and listening skills. The best assignment for dyslexic students will be True / False 
questions, where the student chooses whether a statement is true or false, or multiple choice, where the student must choose answer A, B, C.

For mastering writing skills at the initial stages of training, an assignment in the form of a text with missing words will be effective. These words need to be placed on a separate table and the student will have to select the correct words to fill in the gaps.

The dyslexic student has two main problems in learning grammar: the use of terms to explain grammar rules and the lack of time. You should not start teaching grammar by explaining the rule. It would be advisable to use the technique of "guided discovery" based on the use of the text read or listened to the day before. It is necessary to make sure that students themselves first notice the structure under study in the text - noticing.

The student emphasizes it, finds many examples of this structure. Next, when we explain the rule, we should use a multisensory approach. In this case, it will be effective to use different colors for different parts of the sentence, for example, red for the subject, green for the predicate, etc. In this way, mistakes with the word order in the sentence can be avoided.

Thus, the process of teaching English to students with dyslexia is the activation of their creative activity in order to obtain the required amount of knowledge and use it for all types of communication. In the learning process, it is necessary to use all the senses and various types of memory, it is necessary to rely on visual-spatial, kinesthetic and musical abilities. By following this principle, the most appropriate type of exercise can be selected to suit the abilities of students with reading and writing disabilities.

\section{References:}

1. Корнев А. Н. Нарушения чтения и письма у детей: учебнометодическое пособие. СПб., 1997. 286 с.

2. Лалаева Р.И. Логопедия: Методическое наследие: Пособие для логопедов и студ. дефектол. фак. пед. вузов. М., 2003. 304 с.

3. Ronald D. Davis. The Gift of Dyslexia. Why Some of the Smartest People Can't Read and How They Can Learn. A Perigee Book. New York, 2010. $286 \mathrm{p}$. 